Tempo Social; Rev. Sociol. USP, S. Paulo, 13(2): 1-20, novembro de 2001.

\title{
Política e economia como formas de dominação o trabalho intelectual em Marx
}

\author{
SEDI HIRANO
}

RESUMO: Este ensaio procura sistematizar a análise teórica que Marx faz do pré-capitalismo e do capitalismo como estruturas sociais de poder, predominando naquele as relações políticas e neste as relações econômicas como formas de dominação. Procura-se demonstrar que no pré-capitalismo o poder político e o exercício monopolizado da violência física, social e psicológica são determinados pela forma como os agentes sociais se apropriam das condições objetivas, materiais e simbólicas da produção social. No capitalismo, a produção, quando já é comandada pelo capital, além de produzir a mais-valia, também produz um sistema de exploração geral das propriedades naturais e humanas tendo como suporte a ciência. Ou seja, ela realiza a apropriação através da ciência, e não da violência e do poder pessoal, colocando o saber científico ao seu serviço, na espécie de capital fixo. Essa extração da mais-valia assume, apesar de ser resultante da relação econômica, a forma de atividade científica. É dentro desse contexto que se analisa a questão do trabalho intelectual não só como produtor de valor mas, também, como produtor de concepções justificadoras da forma histórica de poder e de dominação capitalista.

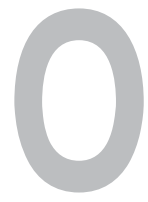

trabalho, na concepção de Marx, "é uma condição natural eterna da existência humana”. Sem o trabalho, não haveria a produção e a reprodução (histórico-social) da vida humana. "O processo de trabalho não é outra coisa senão o próprio trabalho, visto no momento de sua atividade criadora". O homem, sendo o portador consciente da atividade criadora, que se realiza por meio do exercício propositado da força vital, das energias do cérebro e músculos, utilizados conscientemente no processo

PALAVRAS-CHAVE: capitalismo, dominação, trabalho, trabalho intelectual, Karl Marx. 
de conformar e moldar a natureza segundo as necessidades humanas, é agente de transformação, colocando em prática o projeto de dominar as forças naturais e externas ao homem. Para Marx, "os momentos gerais do processo de trabalho, por conseguinte, são independentes de todo desenvolvimento social determinado". Em vista disso, "os meios e materiais de trabalho, dos quais uma parte é já produto de trabalhos precedentes, desempenham seu papel em todo processo de trabalho, em qualquer época e sob quaisquer circunstâncias" (Marx, 1978b, p. 29).

Se a natureza e o homem são os pressupostos da produção material, e se esta é o momento determinado da produção, os fatores fundamentais, quaisquer que sejam as formas sociais de produção, são sempre dois: os meios de produção e os trabalhadores". Por outro lado, "tanto uns como outros são unicamente, enquanto se encontram separados, fatores potenciais de produção". A produção é o resultado da combinação destes fatores. "Suas distintas combinações", afirma Marx, "distinguem as diversas épocas econômicas da estrutura social” (Marx, 1959, Livro II, p. 37).

Estas distintas articulações exprimem formas de vida distintas, formas sociais de produção historicamente determinadas, ressaltando "as diversas épocas econômicas da estrutura social”. Para cada época histórica, existe uma forma social, um modo de atividade social, uma estrutura social, como pressuposto, que comanda e determina a articulação dos momentos fundamentais constitutivos do processo de produção social. Logo, há uma dupla relação no processo de produção: a apropriação natural (material) e a apropriação social, que é determinada pelo modo de atividade social - a relação social de produção. Nesta, a vida social (a cooperação) surge como o momento determinante.

Estas considerações de Marx aparecem tanto nas obras ditas de juventude quanto de maturidade intelectual: "Deve-se evitar antes de tudo fixar a sociedade como abstração frente ao indivíduo. O indivíduo é o ser social” (Marx, 1974, p. 16); "A sociedade é, pois, a plena unidade essencial do homem com a natureza, a verdadeira ressurreição da natureza, o naturalismo acabado no homem e o humanismo acabado da natureza" (Marx, 1974, p. 15); "A produção da vida, tanto da própria, no trabalho, como da alheia, na procriação, aparece agora como dupla relação: de um lado, como uma relação natural, de outro como relação social no sentido de que se entende por isso a cooperação de vários indivíduos, quaisquer que sejam as condições, o modo e a finalidade. Donde se segue que um determinado modo de produção ou uma determinada fase industrial estão constantemente ligados a um determinado modo de cooperação e a uma fase social determinada, e que tal modo de cooperação é, ele próprio, uma 'força produtiva'; segue-se igualmente que a soma de forças produtivas acessíveis aos homens condiciona o estado social (...)" (Marx, 1977, p. 42. Grifos meus).

Às articulações destes diferentes momentos - a produção material e a produção social - e às formas assumidas pelas distintas combinações Marx 
denomina modos de produção. Para cada época histórica, teríamos modos de produzir historicamente determinados.

A vinculação dos agentes sociais coletivos às condições materiais de produção é tanto maior quanto mais a comunidade se erige em pressuposto da produção social. Marx afirma:

"Quanto menor é a força social do meio de troca, quanto maior é a ligação entre a natureza do produto imediato de trabalho e as necessidades daqueles que intercambiam, tanto maior será a força da comunidade que vincula os indivíduos à relação patriarcal, à comunidade antiga, ao feudalismo e à corporação. Cada indivíduo possui o poder social sob a forma de uma coisa. Arrancando-se da coisa este poder social, oferta-se este às pessoas sobre as pessoas. As relações de dependência pessoal (ao principiar sobre uma das bases totalmente natural) são as primeiras formas sociais, nas quais a produtividade humana se desenvolve unicamente num âmbito restrito e em lugares isolados. A independência pessoal fundada na dependência com relação às coisas é a segunda forma importante em que chega a se constituir um sistema de metabolismo social geral, um sistema de relações universais e de capacidade universais. A livre individualidade, fundada no desenvolvimento universal dos indivíduos e na subordinação de sua produtividade coletiva, social, como patrimônio social, constitui o terceiro estádio. No segundo criam-se as condições do terceiro. Tanto as condições patriarcais como as antigas (e também feudais) desagregam-se com o desenvolvimento do comércio, do luxo, do dinheiro, do valor de troca, na mesma medida que e paralelamente com o crescimento da sociedade moderna" (Marx, 1971a, vol. I, p. 85).

Vale destacar que é característica das formações econômico-sociais pré-capitalistas a subsunção do homem como agente de produção seja à comunidade, seja à natureza, seja ao ofício. A comunidade surge, na relação social de produção, como uma entidade superior, que sobrepaira e fecunda as ações entre os homens. A natureza e a política, as condições materiais e as condições jurídico-políticas, e nestas notadamente as ideológicas, estão inextricavelmente articuladas: a natureza, como meio de produção, pertencente a uma entidade comunitária, e o homem, como agente de produção, ou seja, trabalhador. Este, inicialmente, surge como dependente da natureza, na relação homem/natureza; no entanto, esta relação já é o resultado da subsunção do homem à comunidade política. Em outras palavras, as rela- 
ções de produção pré-capitalistas são relações naturais e políticas, aparecendo, a natureza e/ou a política, como o momento destacado da dominação (cf. Marx, 1971a, vol. I, p. 86).

Nas formações econômico-sociais pré-capitalistas, a forma de se apropriar das condições materiais (naturais) e sociais (políticas) simboliza o poder dos agentes sociais. O poder social dos indivíduos é determinado pelo modo como os agentes sociais se inserem nas relações sociais de produção, tendo como núcleo determinante o modo de produção material e as várias modalidades de apropriação da natureza, apropriação que é produção de valores de uso. Quanto maior e mais potenciado é o poder e a capacidade de produzir coisas, maior é o poder social dos indivíduos produtores. O poder social revela-se, na consciência social dos agentes, a partir das condições objetivas de produção, isto é, a partir do resultado da atividade produtiva e do modo pelo qual elas são apropriadas por um grupo social restrito, como o poder personificado no interior da comunidade. O poder social dos indivíduos, gerado pelo processo de produção material, tem como imagem terminal o poder de manipulação e portanto de dominação que certos homens exercem sobre outros homens, no interior da comunidade. Manifesta-se pela posse de objetos materiais e simbólicos de dominação. A posse do aparato material e simbólico de dominação política revela o poder político, que aparece na consciência dos homens como instância última de decisão sobre os destinos dos que vivem imersos na tessitura da organização social comunitária.

O poder político e o exercício monopolizado da violência física, social e psicológica são determinados pela forma como os agentes sociais se apropriam das condições objetivas, materiais e simbólicas da produção social. As relações de dominação e de sujeição pessoal têm como base a propriedade monopolizada sobre a natureza (a terra) e sobre os objetos simbólicos que expressam o poder material - a natureza aparece sendo, e de fato é, o momento privilegiado de expressão da dependência pessoal. Por isso, não se afigura estranho o axioma; "não há terra sem senhor nem senhor sem terra" ("o dinheiro não tem senhor").

Para Marx, a acumulação originária de capital, realizada de forma não-capitalista, pressupõe relações sociais "que produzem um sistema não desenvolvido de troca, de valores de troca de dinheiro". Ainda que estas relações apareçam como relações entre pessoas, que entram em vinculação recíproca como indivíduos com caráter determinado, isto é, como senhor feudal e vassalo, proprietário territorial da gleba, etc., ou então como membro de uma casta, ou ainda como pertencente a um estamento", ocorre que

"nas relações monetárias, no sistema de troca desenvolvido (...) os vínculos de dependência pessoal, as diferenças de sangue, de educação, etc. são de fato destruídos, desmontados (todos os vínculos pessoais se apresentam como relações pessoais) e os indivíduos parecem independentes (esta independência que em si 
mesma é somente uma ilusão que poderia designar-se mais exatamente como indiferença), parecem livres de se enfrentar uns aos outros e de intercambiar nesta liberdade" (Marx, 1971a, vol. I, p. 91).

Destaque-se a afirmação de que o sistema de trocas em desenvolvimento (de circulação) provoca a dissolução dos vínculos de dependência pessoal, baseados ou não nas diferenças de sangue ou de educação: as relações pessoais manifestam-se como relações sociais de troca subsumidas na equivalência entre as mercadorias. Na passagem entre uma e outra forma, temos uma estrutura social de poder que pode assumir tanto as características das castas ou dos estamentos, quanto as de uma estrutura social de dominação fundamentalmente baseada na relação das classes sociais. Afirma Marx que:

"na história real, o trabalho assalariado surge a partir da dissolução da escravidão e da servidão - ou da ruína da propriedade comunal, como ocorre nos povos orientais e eslavos -, e, em sua forma adequada, abre uma época que compreende integralmente a existência social do trabalho, a partir da decadência na qual se fundem a economia corporativa, o sistema estamental, as prestações pessoais e as contribuições em espécie, $a$ indústria praticada como uma atividade rural acessória, $a$ agricultura em pequena escala e ainda de caráter feudal, etc... Em todas essas transições efetivamente históricas, o trabalho assalariado se apresenta como dissolução, como aniquilação de relações, nas quais o trabalho estava fixo em todos os aspectos; em suas rendas, em seu conteúdo, em sua localidade, em seu volume. Ou seja, como negação da fixidez do trabalho e de sua remuneração" (Marx, 1972, vol. III, p. 100-101).

Ao que tudo indica, a questão central da estrutura estamental (e de castas) determina-se numa formação social, onde preexistem relações de dependência pessoal, a economia corporativa, as prestações pessoais, as contribuições fixas em espécie, a indústria como atividade rural e acessória, a agricultura em pequena escala e de caráter feudal, o trabalho como uma atividade sem mobilidade. Em contrapartida, o trabalho assalariado surge com a dissolução da escravidão e da servidão, e de todos os elementos feudais embutidos no processo de trabalho. Convém sublinhar que, para Marx, a "forma comercial e a forma a juros são mais antigas do que a produção capitalista, do que o capital industrial, forma básica da relação de capital"; quando passa a dominar a sociedade burguesa, ela subordina todas as demais formas, transformando-as em formas derivadas secundárias. Originalmente, antes do surgimento do capital industrial, o capital comercial e o capital usurário têm uma atuação revolucionária, dissolvendo as relações feudais e pré-capitalistas: 
"Originariamente, o comércio é o pressuposto da transformação da produção agrícola feudal, das guildas e da produção camponesa caseira, numa produção capitalista. Desenvolve o produto em mercadoria, criando, de um lado, um mercado, de outro, novos equivalentes de mercadoria, além de trazer novos materiais para a produção e abrir com isso novos modos de produção; esses, desde o início, se baseiam no comércio, porque produzem para um mercado ou dependem de elementos da produção que provêm do mercado mundial. (...) o comerciante domina a produção e o capital comercial domina a indústria do artesanato e a indústria camponesa caseira, posta por ele em funcionamento. Os ofícios são seus subalternos". No processo histórico, "a produção se transforma em produção capitalista" (Marx, 1974, p. 279-281).

O capital usurário é, em parte, "um meio de atrofiar" o produtor direto. Com a expansão comercial redobrando a procura de mercadorias pelo estamento comercial, "a empresa corporativa, levada além de seus limites, teve que transformar-se formalmente em empresa capitalista" (Marx, 1978b, p. 54 e 62$)$.

"Na medida em que o capital - não um capital determinado mas o capital em geral - está se formando, é seu processo de formação o processo de dissolução, o produto da separação de um modo de produção social que lhe antecedeu. Portanto processo histórico e pertencente a um determinado período histórico. É o período de sua gênese histórica. (Assim é o modo de ser do homem resultado de um processo anterior pelo qual passou a vida orgânica. Somente num determinado ponto se torna homem. Mas uma vez posto, o homem é pressuposto constante da história humana, do mesmo modo que seu constante produto e resultado; é pressuposição somente na medida em que seu próprio produto é resultado). É apenas aqui que o trabalho tem de separar-se das condições de trabalho na sua forma anterior de identidade com elas. Só assim se torna livre e suas condições se transformam, enfrentando-o, em capital. $O$ processo de vir-a-ser do capital ou de seu desenvolvimento antes do próprio processo capitalista de produção e sua realização neste processo pertencem a dois períodos diferentes do ponto de vista histórico. 
No último é subentendido, pressuposta sua existência como exercendo-se. No primeiro, é a precipitação do processo de dissolução de uma forma social diferente" (Marx, 1974, p. 296-297).

"A usura atua, de um lado, arruinando a riqueza e a propriedade feudal, de outro, a produção de pequenos burgueses e pequenos camponeses; arruinando, em resumo, todas as formas em que o produtor ainda aparece como proprietário de seus meios de produção (...)."

"O usurário tem atuação revolucionária em todos os modos de produção pré-capitalistas, mas apenas de um ponto de vista político, ao destruir e arruinar as formas de propriedade em cuja base firme, a saber, a reprodução constante da mesma forma, se assenta a articulação política. (...) Somente numa época em que se encontram disponíveis as demais condições para uma produção capitalista - trabalho livre, mercado mundial, dissolução do vínculo social antigo, desenvolvimento do trabalho até determinado nível, desenvolvimento da ciência, etc. - é que a usura aparece como meio de constituição de um novo modo de produção; ao mesmo tempo, como ruína dos senhores feudais, colunas do elemento antiburguês, e ruína da pequena indústria, agricultura, etc., em suma, como meio de centralização das condições de trabalho como capital” (Marx, 1974, p. 327 e 328). "Na medida em que a usura faz duas coisas, primeiro, forma em geral bens independentes de dinheiro, segundo, apropria-se das condições de trabalho, o que equivale a arruinar os possuidores das antigas condições de trabalho, ela apresenta um meio poderoso para a constituição das pressuposições do capital industrial - um agente poderoso que separa as condições de produção e os produtores" (Marx, 1974, p. 326).

Na gênese histórica da formação da burguesia comercial ou mercantilista, e na fase final do feudalismo, com a revolução comercial, com o sistema colonial e com o mercado mundial, este segmento acaba emergindo, como força social revolucionária, ou associando-se ou opondo-se aos segmentos sociais dominantes. Isso ocorre, historicamente, tanto pela cooptação política do estamento comercial, quanto pela negação - por parte da fração burguesa - das instituições feudo-estamentais. Nesse processo de realização do estamento comercial ele se afirma como burguesia comercial, depois financeira e, por fim, 
como capitalista industrial. Marx afirma, em seus artigos de jornais, em meados do séc. XIX, diversas vezes, que as revoluções burguesas dos sécs. XVII e XVIII (inglesa e francesa) eram revoluções de classe média (estamentos médios germinados no "terceiro estado") (Marx, 1971b, p. 17). "Não demorou quarenta anos a revolução das classes médias inglesas pela supremacia social e política e quarenta anos a das classes médias francesas, repletas de distúrbios sem paralelo na história?" As palavras alemãs stand e mittelstand são traduzidas por estamento e estamento médio, mas isto não ocorre na maioria das traduções, onde stand e mittelstand, empregadas algumas vezes por Marx, são traduzidas por classes e classes médias (cf., por exemplo, Marx, s.d., p. 101-124).

Essas classes médias eram segmentos sociais residuais e secundários, que, em um processo de transformação da burguesia em burguesia capitalista, metamorfosearam-se em comerciantes de mercadorias na circulação simples, portanto, em usuários e simples mercadores. Com o processo de acumulação originária de capital, foram transformados em burguesia mercantilista (comercial e financeira). Trata-se de um processo histórico de realização da burguesia, antes de ser burguesia capitalista (industrial). No processo histórico de realização da burguesia em burguesia capitalista, ocorre também o processo de dissolução das relações de produção pré-capitalistas, a destruição das relações sociais estamentais e a passagem da burguesia de estamento comercial a classe capitalista dominante.

$\mathrm{Na}$ fase de transição do pré-capitalismo ao capitalismo, a burguesia se realiza como burguesia no processo de circulação, que é elemento do processo histórico de acumulação originária de capital. Na fase final deste processo, desloca-se o comando e a condição da produção para a esfera da circulação, assegurando-se ao capital comercial enquanto "estamento comercial" "o domínio sobre o capital produtivo". O processo histórico de vir-a-ser de uma burguesia que detém o capital comercial, em burguesia possuidora do capital industrial, é também um processo de dissolução e de transformação revolucionária: dissolução, que separa os produtores dos meios de produção, e prepara historicamente as condições objetivas para que apareçam, ulteriormente, os fatores fundamentais necessários à produção capitalista: meios de produção, de um lado, trabalhadores livres-assalariados, de outro (cf. Marx, 1974, p. 279-328; 1959, Livro III, vol. V, p. 376-388).

A burguesia comercial, com seus papéis na esfera da circulação e no processo de acumulação originária de capital, apropria-se politicamente do excedente produzido nos modos de produção prevalecentes. Focalizando o movimento histórico de realização da burguesia comercial (mercantil), que se dá em qualquer formação histórica, na esfera da circulação - esfera esta efetivamente autônoma em relação aos modos de produção pré-capitalistas - percebe-se que a gênese histórica da burguesia industrial é também o movimento de transformação do capital acumulado de uma forma não-capitalista em capitalista. Ele corresponde à própria gênese histórica da transformação do estamento comercial em burguesia industrial, isto é, à história da constituição da burguesia em classe dominante. 
Para Marx, o percurso "realmente revolucionário", isto é, de transformações históricas radicais, corresponde à "transformação do produtor em comerciante e em capitalista, em oposição à economia natural agrícola e ao artesanato corporativo da indústria medieval". Outra via é a do comerciante apoderando-se diretamente da produção. "Este último caminho", diz Marx, "embora constitua uma fase de transição histórica, de per si não consegue revolucionar o velho modo de produção, que conserva e mantém como condição fundamental".

\section{Inglaterra}

É na Inglaterra que o capital comercial e o sistema colonial, por meio dos quais se realiza a acumulação originária de capital, prenunciam o advento do modo de produção capitalista. Ao contrário do que acontecia com a marinha portuguesa, nos sécs. XVI e XVII, monopolizada pelo estamento nobre, a marinha inglesa dos sécs. XVII e XVIII era uma organização, segundo Hobsbawn, "de classe média" (isto é, estamento médio pertencente ao terceiro estado). Tal observação deixa entrever o caráter qualitativamente distintivo da acumulação originária na Inglaterra.

Os historiadores britânicos nos lembram com razão que o Parlamento Britânico era controlado por uma oligarquia de aristocratas proprietários de terras e não por aquelas classes que ainda não eram chamadas de médias. No entanto, segundo os princípios continentais, quão pouco aristocráticos eram aqueles nobres! Todo o sistema britânico se baseava, ao contrário do que sucedia em países menos prósperos, num governo voltado para as necessidades daquela que o Abade Coyer (1779) chamava 'a classe média honesta, aquela preciosa parcela das nações'. O comércio que enriqueceu os cidadãos da Inglaterra - escrevia Voltaire - contribuiu para torná-los livres, e essa liberdade, por sua vez, expandiu o comércio. Esse é o fundamento da grandeza do Estado (cf. Hobsbawn, 1978, p. 23-26).

A Inglaterra, portanto, impressionava os observadores como um país que tinha no comércio ultramarino a fonte alimentadora do organismo econômico, que dominava e recobria toda a nação: "era uma nação de lojistas", na qual o cidadão exemplar era o comerciante e não o industrial.

Por intermédio da atividade comercial é que o cidadão médio britânico se emancipou e essa liberdade contribuiu por sua vez para expandir o comércio. As idéias de liberdade e classe média tornaram-se intimamente ligadas à troca monetária, às relações econômicas. Por meio delas os homens se libertaram da compulsão política e do arbítrio do poder pessoal. E isso porque a relação econômica acabou por se transformar em uma relação entre coisas, não dotadas de personalidade, desaparecendo a dependência pessoal.

É na Inglaterra que historicamente se conjugam os elementos econômicos, sociais e políticos, que resultaram na revolução industrial das três últimas décadas do séc. XVIII, prenunciando o advento do modo capitalista de produção e, embutidas nele, as classes sociais. Essa história é a 
história de todos os segmentos sociais do terceiro estado, que se transformaram em capitalistas, proletários e pequenos burgueses ou "classes médias". Em 1779, o abade Coyer bradava: "Meditai nisso, vós que ainda suportais um sistema de regulamentos e de privilégios régios de monopólio, ao observar que até mesmo estradas e canais eram construídos e mantidos pela motivação do lucro".

Para Hobsbawn, por detrás da revolução industrial, identificada como tal já a partir de 1770, avulta um comércio pela concentração dos mercados coloniais do ultramar na mão dos mercadores ingleses, sob a forma de monopólio quase exclusivo de intercâmbio com a China (em 1766, vendendo mais que a Holanda), e com a África (em 1780 mais da metade de todos os escravos ali caçados para venda):

\section{"Nossa economia industrial desenvolveu-se a par- tir de nosso comércio (...). \\ Enquanto se engrossava a corrente das trocas in- ternacionais, em certo momento de meados do séc. XVIII tornou-se perceptivel um aceleramento das economias internas (...). A revolução industrial foi gerada nessas décadas, após a década de 1740, quando esse amplo, mas lento, crescimento das eco- nomias nacionais juntou-se à expansão rápida - após 1750, rapidíssima - da economia internacio- nal. E ocorreu no país que aproveitou suas oportu- nidades internacionais para açambarcar uma par- cela substancial dos mercados ultramarinos" (Hobsbawn, 1978, p. 27, 50-51).}

Desta classe-média, que realiza historicamente o processo de transformação econômica, e que é representada pelo estamento comercial ou estamento mercantil, em conformidade com a linguagem de Marx, podemos afirmar que ela é produto da rapidíssima expansão da economia internacional.

Em contrapartida, no processo de realização do modo de produção capitalista, numa dada formação econômico-social, quando ocorre a transição da fase de produção de mais-valia absoluta para a fase de produção de maisvalia relativa, o desenvolvimento das forças produtivas potencia-se dinamicamente, com a incorporação da ciência e da tecnologia, com a utilização crescente de dispositivos automáticos. Nesse processo de verdadeira industrialização, é gerada a estrutura de classes.

$\mathrm{Na}$ fase manufatureira do desenvolvimento capitalista, a coordenação intelectual do processo de trabalho e o planejamento consciente do trabalho diretamente produtivo são ainda articulados e efetuados em conjunto pelos capitalistas e pelos trabalhadores assalariados, mas estes já se subordinam, pelo menos formalmente, ao capital. São classes sociais fundamentais, opostas. Na fase de reprodução ampliada do capital, o trabalho diretamente produtivo torna-se cada vez mais um trabalho simples, fragmentado e 
apendicular, necessitando a mediação do trabalho técnico-científico para a sua programação e o seu planejamento material.

No desenvolvimento das forças produtivas, enquanto um processo de produção ampliada do capital, o trabalho técnico-científico (intelectual) emerge como o momento mediador determinante e dominante do trabalho simples. O desenvolvimento das forças produtivas, que pertencem ao capital, amplia cada vez mais o espaço destinado ao trabalho técnico-científico, estreitando, em contrapartida, o espaço ocupado pelo trabalho direto, transformando-o cada vez mais em trabalho apendicular do capital fixo.

Deste modo, no processo de desenvolvimento histórico da produção capitalista, ao chegar à etapa monopolista, manifesta-se, na esfera da produção, um espaço necessário para o trabalho de planejamento, programação e controle, resultante do desenvolvimento científico já alcançado pelas forças produtivas. $\mathrm{O}$ trabalho técnico-científico, agora essencial à produção capitalista, passa a ser determinante e dominante - e momento de mediação necessária à realização do trabalho diretamente produtivo.

O desenvolvimento das forças produtivas, comandadas e "fundadas no capital", pressupõe, necessariamente, a razão científica, na forma de razão técnica, como um momento mediador determinante: a razão que calcula a lógica do processo de acumulação capitalista. Não temos dúvida de que Marx pensa em uma dupla sobreposição dos capitais, ou, mais especificamente, do capital fixo: uma sobreposição, em relação ao trabalho imediato, diretamente produtivo e subalterno do "trabalho científico geral", e outra sobreposição, a do "trabalho científico geral" que, embora determinante, subordina-se ao capital, cujo processo histórico de realização é a paulatina absorção do espaço do trabalho produtivo. Marx esclarece que "a acumulação do saber e da natureza, das forças produtivas gerais do cérebro social, é absorvida assim pelo capital, e se apresenta finalmente como propriedade do capital, e mais precisamente do capital fixo, na medida em que este ingressa como verdadeiro meio de produção no processo produtivo" (Marx, 1972, vol. II, p. 220).

Pode-se afirmar que no modo de produção capitalista:

- em primeiro lugar, o saber rigoroso e o conhecimento técnicocientífico desempenham um papel dominante e determinante, na "transformação do processo produtivo a partir do processo simples de trabalho num processo científico" (Marx, 1972, vol. II, p. 222);

- em segundo lugar, a produção do saber social geral e da ciência, como resultado do "esforço do homem", corresponde ao "sujeito que se apresenta no processo de produção, não sob uma forma meramente natural, espontânea, mas como atividade que regula todas as forças da natureza" (Marx, 1972, vol. II, p. 120);

- em terceiro lugar, a "criação da riqueza efetiva torna-se menos dependente do tempo de trabalho" e do volume de trabalho utilizado, fazendo-se, cada vez mais, dependente e subsumido ao "poder dos agentes postos em movimento", que resulta do desenvolvimento geral da ciência e do pro- 
gresso tecnológico, ou seja, da utilização do conhecimento científicotecnológico na produção capitalista;

• e, em último lugar, é desse modo que se instaura a subsunção real do trabalho científico ao capital.

A transformação do processo simples de trabalho em processo científico de trabalho é comandada pelo capital, posto que este, além de produzir "a indústria universal - ou seja, sobretrabalho, trabalho criador de valor também produz um sistema de exploração geral das propriedades naturais e humanas, um sistema de utilidades geral. O capital cria assim a sociedade burguesa e a apropriação universal tanto da natureza quanto da própria relação social pelos membros da sociedade. Daí a grande influência civilizadora do capital; sua produção de um nível de sociedade em face à qual todos os anteriores aparecem como desenvolvimentos meramente locais da humanidade e como uma idolatria da natureza" (Marx, 1971a, vol. I, p. 361-362).

A produção, quando já é comandada pelo capital, além de produzir a mais-valia, também produz um sistema de exploração e dominação geral das propriedades naturais e humanas tendo como suporte a ciência. Ou seja, ela realiza a apropriação através da ciência, não da violência e do poder pessoal, colocando o saber científico ao seu serviço, na espécie de capital fixo, diferentemente do escravo, que é apropriado pessoalmente, e não socialmente. Essa apropriação do conhecimento científico nada custa ao capital, o que não ocorre com o escravo, enquanto uma modalidade de capital fixo. A ciência se apresenta, perante o capital, como um "saber acumulado da sociedade" ("ciência experimental, ciência que se objetiva e é materialmente criadora"). E o capital somente pode se apropriar da potência científica (scientific power) "mediante o emprego da maquinaria" (Marx, 1972, vol. II, p. 236, 302 e passim).

Convém lembrar que o capital que se apropria do trabalho escravo como capital fixo, com um elevado custo, e só operado por meio da compulsão, não pertence ao capital industrial, que requer o trabalhador livre assalariado; o escravo, no seu conceito, pertence ao modo de produção mercantil escravista, que não é capitalista: se fosse possível admitir um caráter capitalista à escravidão, a revolução industrial em sua modalidade escravista teria ocorrido com anterioridade nas colônias e não nas metrópoles, o que seria um absurdo histórico. A potência científica, enquanto elemento assimilado à produção, é meio de produção e capital fixo. Essa assimilação do conhecimento científico, realizada pela apropriação capitalista do saber social geral, é tendência da produção e reprodução capitalista, em sua fase avançada.

Essa ciência, que se objetiva e que é materialmente criadora, é capturada pelo capital. Com o advento da produção fundada no capital, o progresso social ("o desenvolvimento histórico, o desenvolvimento político, a arte, a ciência, etc." - que "se desenvolviam nas altas esferas", acima e à parte das formas sociais pré-capitalistas de produção) é capturado pelo capital e passa a pertencer ao capital (cf. Marx, 1972, vol. II, p. 91-92 e 308). 
O desenvolvimento das forças produtivas é, também, o desenvolvimento da potência científica. A acumulação capitalista é, assim, acumulação do saber e da destreza, "das forças produtivas gerais do cérebro social". O desenvolvimento das forças produtivas "da sociedade mede-se pelo capital fixo, existe nele em forma objetiva e (...) a força produtiva do capital se desenvolve com este progresso geral, de que o capital se apropria gratuitamente" (Marx, 1972, vol. II, p. 220-221 e 1959, Livro I, p. 293-294).

O desenvolvimento das forças produtivas, baseado no trabalho escravo, pertence à fase pré-capitalista. O escravo, como mercadoria, tem um custo para o capital mercantil. Este, em sua forma de acumulação originária, faz-se sem a interferência do conhecimento científico, mas quando o capital já é o elemento da produção capitalista, a ciência e a técnica constituem "uma potência para expandir o capital, independentemente da magnitude dada do capital em funcionamento": elas "atuam conjuntamente sobre a parte do capital" original-capitalista que "esteja sendo renovada", O capital incorpora gratuitamente em sua nova forma o progresso social que se realizou sem qualquer interferência de sua forma antiga” (Marx, 1959, Livro I, vol. II, p. 510).

A ciência e a técnica são uma espécie de saber, o conhecimento objetivado. Elas se realizam pela vontade humana, no intercurso do homem com a natureza, posto que, como diz Marx, a natureza não constrói artefatos mecânicos automáticos, nem a ciência ou a tecnologia. Tudo isso são "órgãos do cérebro humano, criados pela mão humana: força objetiva do conhecimento". Com o desenvolvimento das forças produtivas e, mais especificamente, do capital fixo, "o conhecimento (o saber social geral) se converteu em força produtiva imediata”. Essa conversão do saber social geral - a ciência e a tecnologia - em "órgãos imediatos da prática social, do processo vital real", realiza-se por meio do capital e pela apropriação capitalista do "intelecto coletivo", que é posto a serviço do processo de produção e reprodução capitalista.

A produção capitalista depende cada vez menos do trabalho diretamente produtivo, ao contrário do que ocorre com a produção não-capitalista, baseada na apropriação do ser humano como instrumento de produção, que requer o trabalho escravo como uma máquina viva de trabalho. A maquinaria e os dispositivos mecânicos automáticos, enquanto um conhecimento realizado, são absorvidos pelo capital, na forma de capital fixo, transformando-se, no processo de produção capitalista, em instrumento de realização e de apropriação do sobrevalor, ao regular e moldar o espaço, o ritmo e a destreza do trabalho necessário, diretamente produtivo.

No nosso modo de entender, há dois tipos de trabalho necessário, não diretamente produtivos, envolvidos na passagem da produção do conhecimento científico para uma produção em que este ganha aplicação tecnológica. No primeiro caso, o trabalho necessário não está diretamente vinculado à produção capitalista, ele é independente em relação a ela, e é "inteiramente livre, sério e realizado com intenso esforço", de "índole científica", e no qual o 
homem se apresenta como "sujeito no processo de produção", "atividade que regula todas as forças da natureza” (Marx, 1972, vol. II, p. 120).

Do ponto de vista do capital, esse trabalho de produção científica não é diretamente produtivo. É um trabalho que produz conhecimento científico enquanto mero valor de uso, ou seja, um saber acumulado da sociedade ("ciência experimental, ciência que se objetiva e é materialmente criadora”). Por ser um saber acumulado da sociedade, a produção científica é uma produção material de caráter social, e por esta razão pode ainda ter um caráter mercantil e estar subsumida ao capital, devendo, neste caso, ser apropriada de forma privada pelo capital. Se o trabalho técnico-científico, do ponto de vista do capital, não é, no primeiro caso, produtivo, já no segundo caso, do ponto de vista da sociedade, é posto como trabalho necessário ao desenvolvimento das forças produtivas, e materialmente criador. Veja-se que, para Marx, "as forças naturais e a ciência" são o produto "do desenvolvimento histórico geral em sua quinta-essência abstrata". A utilização e criação da "ciência, das forças naturais e dos produtos do trabalho em grandes quantidades, - fundada no trabalho social -, não surgem ante o trabalho senão como meios de exploração do trabalho, como meios de apropriar-se do trabalho excedente, e, portanto, como forças pertencentes ao capital". Desse modo, o trabalho técnico-científico, quando subsumido ao capital, não só é produtivo como criador de utilidade mas, também, como forma de se apropriar do excedente em forma de mais-valia.

Tal como foi demonstrado na análise do trabalho compulsório, a extração do excedente se fazia através da violência pessoal (da política). No trabalho livre assalariado, subsumido formalmente ao capital, a extração de mais-valia é resultado de relação econômica (de caráter puramente monetário). Quando ocorre subsunção real do trabalho livre assalariado ao capital, a extração da mais-valia assume, apesar de ser resultante da relação econômi$c a$, a forma de atividade científica. O capital, naturalmente, só utiliza esses meios de explorar o trabalho (num deles estendendo a jornada de trabalho e noutro aumentando a produtividade do trabalho) com a aplicação de ciência e tecnologia. Em conseqüência, para Marx, toda "classe intelectual se encontra colocada também sob a dependência dos capitalistas", de modo que "a livre produção intelectual é própria desta organização social concreta". Essa classe intelectual, formalmente livre, constitui a força legitimadora das "classes dirigentes", produtora não só dos “elementos ideológicos, das concepções intelectuais imperantes" mas, também, enquanto produtora da ciência e da tecnologia, dos meios de produção (valores de uso) utilizados pelo capital, na forma de capital fixo, para explorar trabalho alheio (cf. Marx, 1978b, p. 8687 e 1978a, p. 151 e 202).

Do exposto, depreende-se que, além do trabalho técnico-científico, produtor do valor de uso, de que o capital se apropria como meio de produção momento necessário e fundante do desenvolvimento das forças produtivas -, existe outro tipo de trabalho excedente, não imediatamente vinculado à produção imediata, e que é um trabalho intelectual, produtor de concepções 
justificadoras da forma histórica capitalista, para alçá-la à condição de ser imperante e dominante.

Marx afirma que na "produção intelectual se revela como produtiva outra classe de trabalho", que é determinada pela produção material, em sua "forma histórica determinada e concreta". Para Marx, existe uma "correlação" ou uma "interdependência" entre essas duas classes de produção. Segundo Marx, "uma forma determinada de produção material supõe, em primeiro lugar, uma determinada organização da sociedade e, em segundo lugar, uma relação determinada entre o homem e a natureza”. Em vista disso, “o sistema político e as concepções intelectuais imperantes dependem destes dois pontos". Ecomo consequiência, também o tipo da produção intelectual. Essa interdependência entre a produção intelectual e a produção material permite "compreender tanto os elementos ideológicos das classes dirigentes como a livre produção intelectual própria desta organização social concreta". É nesse sentido que Marx afirma ser o trabalho intelectual produtor de "um valor de uso, real ou imaginário" (Marx, 1978a, p. 201-203).

Para Marx, o trabalho, que produz ideologias e concepções intelectuais imperantes, é determinado pela produção material. Esse tipo de trabalho intelectual constitui uma força legitimadora e mantenedora do sistema político enquanto "organização social concreta" — real ou imaginária — de dominação. Nas formas sociais que precedem o modo de produção capitalista, esses ideólogos eram membros do estamento eclesiástico e legista, provenientes do terceiro estado, que justificavam o uso da violência por intermédio da doutrina da guerra justa e da teoria do direito natural, como se a desigualdade fosse posta pela natureza na qualidade de atributo de vontade divina.

Enquanto o trabalhador intelectual, localizado na supra-estrutura, produz o valor de uso na espécie social de meio de dominação do capital, o trabalho técnico-científico - uma modalidade de trabalho intelectual - produz o valor de uso como elemento intelectual objetivado que potencializa as forças produtivas do capital. Ele aparece como algo natural, inerente à sociedade, disponível ao capital. Esse trabalho necessário, indiretamente produtivo, que nada custa ao capital, é essencial ao desenvolvimento das forças produtivas.

O consumo do resultado da atividade científica, como meio de produção, transforma essa modalidade de trabalho em atividade necessária à reprodução capitalista, um trabalho que produz valor de uso para o capital. Por outro lado, o trabalho técnico-científico pode estar formal ou realmente subsumido no capital. Está formalmente subsumido no capital quando a este diretamente se vincula; nele já está presente um saber, que é anterior à sua inserção no processo de produção capitalista. Aliás, o capital, quando se apropria da força de trabalho, apropria-se não só de uma capacidade útil de trabalho mas, também, de um saber, de modo geral presente no trabalhador. Isso não ocorre com o trabalho escravo, na medida em que é um mero instrumento passivo da produção. $\mathrm{O}$ trabalhador, quando está apenas formalmente subsumido ao capital, ainda incorpora em si a maioria das forças produtivas da sociedade, na forma da maior parte do "saber social" produzido no âmbito dessa sociedade. 
Para Marx, todo trabalho produtivo nesse sentido é trabalho livre assalariado. De acordo com ele, com o

"desenvolvimento da subsunção real do trabalho ao capital ou do modo especificamente capitalista, não é o operário individual, mas uma crescente capacidade de trabalho socialmente combinada que se converte no agente (Funktionär) real do processo de trabalho total, $e$ como as diversas capacidades de trabalho que cooperame formam a máquina produtiva total participam de maneira muito diferente no processo imediato da formação de mercadorias, ou melhor, de produtos - este trabalha mais com as mãos, aquele trabalha mais com a cabeça, um como diretor (manager), engenheiro (engineer), técnico, outro, como capataz (overlooker), um outro como operário manual direto, ou inclusive como simples ajudante -, temos que mais e mais funções da capacidade de trabalho se incluem no conceito imediato de trabalho produtivo, e seus agentes no conceito de trabalhadores produtivos, diretamente explorados e subordinados em geral a seu processo de valorização e de produção. Se se considera o trabalhador coletivo, que se constitui na oficina, sua atividade combinada se realiza materialmente (materialiter) e de maneira direta num produto total que, ao mesmo tempo, é um volume total de mercadorias; é absolutamente indiferente que a função de tal ou qual trabalhadorsimples elo desse trabalhador coletivo - esteja mais próxima ou mais distante do trabalho manual direto. Mas, então, a atividade dessa capacidade de trabalho coletiva é seu consumo produtivo direto pelo capital, vale dizer, o processo de auto-valorização do capital, a produção direta de mais-valia, e daí, como analisar-se-á adiante, a transformação direta da mesma em capital” (Marx, 1978b, p. 71-72; grifos no original). "O produto específico do processo capitalista de produção - a mais-valia - é gerado somente pela troca com o trabalho produtivo" (Marx, 1978b, p. 75). "Todo trabalhador produtivo é assalariado, mas nem todo assalariado é trabalhador produtivo" (Marx, 1978b, p. 72).

Um trabalhador tecnicamente qualificado faz parte da "capacidade de trabalho socialmente combinada", que é uma atividade combinada que se apresenta em um produto total. Este "volume total de mercadorias" resulta da atividade combinada do operário manual e do "operário" intelectual, ambos 
integrando a "classe proletária" ou "classe produtiva", e subsumidos ao capital. Enquanto o operário "trabalha mais com as mãos", outros trabalham "mais com a cabeça". Os trabalhadores que operam com o cérebro (diretor, engenheiro, técnico, etc.), mais os que operam como vigilantes e capatazes, mais os que operam com as mãos (modalidades de trabalhador-operário, de qualificações diversas) formam o que Marx denomina de capacidade de trabalho socialmente combinada. Aqueles que personificam as diversas modalidades de trabalho operário propriamente dito (trabalho manual), trabalhadores técnico-científicos, trabalhadores de direção e vigilância (capatazes) entram na categoria de trabalhador coletivo assalariado, e são os agentes reais do processo de trabalho total, formando a máquina produtiva total, e se incluem, no dizer de Marx, "no conceito de trabalhadores produtivos, diretamente explorados pelo capital e subordinados em geral a seu processo de valorização e de produção".

Essa atividade do trabalhador coletivo, isto é, a articulação da diversidade de capacidades de trabalho numa totalidade socialmente combinada, "se realiza materialmente e de maneira direta num produto total". Esse volume total de mercadorias é a materialização da produção e reprodução capitalista em escala. Portanto, o capital consome a capacidade de trabalho coletiva, de uma forma diretamente produtiva, produzindo imediatamente a mais-valia em processo de autovalorização do capital. A capacidade de trabalho, como força de trabalho, "só pode aparecer como mercadoria no mercado, enquanto for e por ser oferecida ou vendida como mercadoria pelo seu próprio possuidor, pela pessoa da qual ela é a força de trabalho", ou seja:

"A fim de que seu possuidor a venda como mercado-
ria, é mister que ele possa dispor dela, que seja pro-
prietário livre de sua capacidade de trabalho, de sua
pessoa" (Marx, 1959, Livro I, p. 121-122).

Logo, para Marx, a relação entre capital e trabalho manifesta-se como se fosse a simples relação entre "possuidores de mercadorias, dotados de igual condição, diferenciando-se apenas por um ser o vendedor e o outro comprador, sendo ambos juridicamente iguais". O trabalhador vende a sua força de trabalho por um tempo determinado, o que não ocorre nas formas que precedem à produção capitalista (Marx, 1959, Livro 1, p. 121-122).

Para Marx, "só aparece o capital quando o possuidor de meios de produção e de subsistência encontra o trabalhador livre no mercado vendendo sua força de trabalho, e esta única condição histórica determina um período da história da humanidade". Ele conclui afirmando: "o capital anuncia, desde o início, uma nova época no processo de produção social” (Marx, 1959, Livro I, p. 123).

No nosso modo de entender, torna-se imprescindível marcar as diversas modalidades de trabalho, em seus vários momentos. Se ressaltamos unilateralmente o ser e o vir-a-ser do trabalho intelectual (trabalho técnicocientífico), dando primazia à produção capitalista, temos duas modalidades de trabalho intelectual ou científico como produtoras de valor de uso, logo, necessárias, mas só indiretamente produtivas. 
Uma é todo saber acumulado da sociedade, que nada custa ao capital, mas pode vir a ser apropriado pelo capital. A outra, o saber acumulado como instrumento ideológico de dominação do capital, que legitima a produção fundada no capital. Em outras palavras, há dois processos de produção do saber: um deles é o do saber que domina a natureza, controlando-a e modificando-a; o outro é o saber social, a ciência específica do social, que controla a relação entre os homens, produzindo as formas ideológicas e político-jurídicas de dominação. Essa dominação ideológica e jurídico-política, na produção capitalista, aparece, apesar de ser produto de um longo processo histórico, como uma fórmula natural, promotora de igualdade jurídica na esfera da circulação; e como produtora de igualdade e liberdade sem contingenciamentos na esfera de produção. Nesta, a apropriação, pelo capital, do saber social e natural, acumulados pela sociedade, e que antes desta época histórica não pertenciam ao capital, fazem dele um saber privativo.

Mas distingue-se, ainda, um trabalho técnico-científico de organização, que se insere no processo de trabalho, entendido este como capacidade de trabalho socialmente combinada, e que se apossa paulatinamente do saber prático e intelectual do trabalhador operário manual, esvaziando, sucessivamente, com o desenvolvimento das forças produtivas, as tarefas, ainda de posse do operário, de planejamento, programação e organização do processo de trabalho capitalista. Esse trabalhador de organização gerencial e de supervisão técnica, como parte integrante da capacidade de trabalho socialmente combinada, é um trabalhador coletivo (e uma classe social) e realiza um trabalho necessário, determinante e diretamente produtivo. Determinante, na medida em que o processo de produçãoe reprodução capitalista, em escala ampliada, tem por base esse trabalho intelectual de coordenação e de supervisão tecnológica, sendo elemento constitutivo do mesmo, como momento necessário de mediação no processo de mais-valia relativa.

Reiterando, existem, tanto na infra-estrutura quanto na supraestrutura, modalidades historicamente produzidas de trabalho intelectual.

Na infra-estrutura, temos uma modalidade de trabalho técnico-científico diretamente produtiva. Uma vez que o trabalho diretamente produtivo funda uma das classes sociais fundamentais, o trabalhador técnico-científico (tal como o trabalhador manual), enquanto personificação do trabalho diretamente subsumido ao capital, pertence à classe dominada. Se traduzimos classe dominada por classe operária, o trabalhador técnico-científico, como trabalhador livre assalariado, subordinado ao capital, é um instrumento de racionalização no processo de extração da mais-valia. Ele se põe, no processo de trabalho, como uma capacidade de trabalho socialmente combinada que, além de ser capacidade produtiva, aparece com funções de ordenação e organização no processo de produção. Manifesta-se, em relação aos trabalhadores manuais diretamente produtivos, como agente de dominação da classe proprietária de capital, embora pertença à classe dominada. O capital realiza a sua dominação por intermédio do trabalhador técnico-científico, mas este, por seu lado, está subordinado ao capitalista industrial.

Finalmente, na superestrutura, como já vimos, os trabalhadores do pensamento são produtores dos elementos intelectuais das formas de domina- 
ção. Eles produzem não só a ideologia dominante e com vigência social, mas, também, as organizações sociais concretas de dominação da classe dirigente. Eles são instrumentos de realização dessa dominação de classe, a dominação do capital, ao produzirem e reproduzirem "os sistemas políticos e as concepções intelectuais imperantes", que dependem, segundo Marx, de uma determinada forma de produção material. E esta supõe uma "determinada organização da sociedade" e uma "relação determinada entre o homem e a natureza". Portanto, segundo a concepção marxista, existe uma correlação ou uma interdependência "entre estas duas classes de produção".

Uma vez que as concepções intelectuais e o sistema político imperantes são produtos do trabalho intelectual, determinado em última instância pela produção material capitalista, essa produção material também coloca como necessária uma "superestrutura de camadas ideológicas (...), a serviço do capitalista (que) resulta em benefício deste". Por consequiência, esses trabalhadores intelectuais realizam a produção de elementos ideológicos, comandados pelo capital, numa relação formal de subalternidade e determinidade, face ao capital. Nesse sentido, são classes assalariadas subalternas ao capital, alocadas na supra-estrutura jurídico-política. Essas características de classes sociais fundamentais, reveladas nos agentes que realizam o trabalho diretamente produtivo, como capacidade de trabatho socialmente combinada, indicam que o trabalho que produz mais-valia na sua forma relativa é específico ao modo de produção capitalista, posto que só nele o trabalho técnico-científico adquire uma espessura e uma importância qualitativa que o torna poder determinante e fundante da produção da mais-valia relativa. A ciência e a tecnologia tornaram-se, desde então, os elementos fundamentais da produção capitalista e, a partir dessa estrutura, a classe operária se desdobra entre aqueles que apenas realizam o trabalho de concepção e os que tão só fazem o trabalho de execução. Essa subdivisão não ocorria na fase manufatureira, quando a produção capitalista produzia sobre-valor por meio do prolongamento da jornada de trabalho, extraindo mais-valia absoluta.

Essa fase de transição da produção de mais-valia absoluta para a de mais-valia relativa só se inicia a partir da segunda metade de séc. XVIII. Até aquela data, segundo Marx, "o trabalho assalariado não se realiza plenamente na Inglaterra". Portanto, no país pioneiro, que se converteu "na oficina mecânica do mundo", a revolução industrial só principia a partir de 1780. 
KEY WORDS:

capitalism, domination, labor, intellectual labor, Karl Marx.
HIRANO, Sedi. Politics and economy as forms of domination: intellectual labor in Marx. Tempo Social; Rev. Sociol. USP, S. Paulo, 13(2): 1-20, November 2001.

ABSTRACT: This essay aims at systematizing the theoretical analysis that Marx makes of pre-capitalism and of capitalism as social structures of power, bearing in mind that political relations predominate in the former and economic relations in the latter as forms of domination. In pre-capitalism, political power and the monopolized exercise of physical, social and psychological violence are determined by the manner in which social agents appropriate objective, material and symbolic conditions of social production. In capitalism, production, when it is already commanded by capital, on top of producing surplus value, it also produces a system of general exploitation of the natural and human properties with the support of science. In other words, it fulfills the appropriation through science and not violence or personal power, putting scientific knowledge at its service, in the form of fixed capital. This extraction of surplus value takes on the form of scientific activity, in spite of being a result of the economic relationship. It is within this context that the analysis of intellectual labor is made, not only as value producer, but also as producer of concepts to justify the historical forms of power and of capitalist domination.

\section{REFERÊNCIASBIBUOGRÁFICAS}

Hobsbawn, Eric J. (1972) En torno a los origenes de la revolución industri$a l$, Buenos Aires, Siglo XXI.

. (1978) Da revolução industrial inglesa ao imperialismo. Rio de Janeiro, Forense Universitária.

. (1982) A era do capital. Rio de Janeiro, Paz e Terra.

MARX, Karl. (s/d) Crítica da filosofia do direito de Hegel. Lisboa, Editorial Presença.

. (1959) El capital. Livros I, II e III. México, FCE.

. (1971a) Elementos fundamentales para la critica de la economia política. Vol. I, Buenos Aires, Editora Siglo XXI.

. (1971b) Revolução e contra-revolução. Lisboa, Editora M. Rodrigues Xavier.

. (1972) Elementos fundamentales para la critica de la economia política. Vols. II e III, Buenos Aires, Editora Siglo XXI.

. (1974) Karl Marx. Col. Os Pensadores. São Paulo, Abril Cultural. . (1977) A ideologia alemã. São Paulo, Editora Grijalbo.

. (1978a) História crítica de la teoria de la plusvalia. Tomo 1, Buenos Aires, Editora Brumário.

(1978b) O capital. Capítulo VI (inédito), São Paulo, Editora Ciências Humanas. 